\title{
Fibrinous pleuropneumonia caused by Pasteurella multocida associated with bovine lymphoma
}

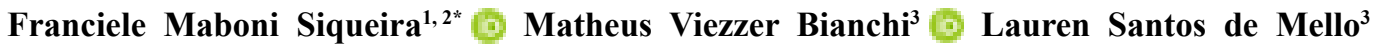 \\ Marina Paula Lorenzett ${ }^{3}$ Luciana Sonne $^{1,3}$ Gustavo Geraldo Snell $^{3}$ \\ Saulo Petinatti Pavarini, ${ }^{1,3}$ David Driemeier ${ }^{1,3}$
}

'Departamento de Patologia Clínica Veterinária, Faculdade de Veterinária (FAVET), Universidade Federal do Rio Grande do Sul (UFRGS), Porto Alegre, RS, Brasil.

${ }^{2}$ Laboratório de Bacteriologia Veterinária, Faculdade de Veterinária (FAVET), Universidade Federal do Rio Grande do Sul (UFRGS), Av. Bento Gonçalves, 9090, 91540-000, Porto Alegre, RS, Brasil. E-mail: franmaboni@gmail.com. *Corresponding author.

${ }^{3}$ Setor de Patologia Veterinária, Faculdade de Veterinária (FAVET), Universidade Federal do Rio Grande do Sul (UFRGS), Porto Alegre, RS, Brasil.

\begin{abstract}
In this work, we describe an unusual case of fibrinous pleuropneumonia caused by Pasteurella multocida associated with generalized lymphadenomegaly in a bovine. The animal had a one-month history of generalized superficial lymphadenomegaly that progressed to anorexia and submandibular oedema, resulting in spontaneous death. At necropsy, the parenchyma of the lymph nodes and multiple organs was obliterated by a dense proliferation of round neoplastic cells (lymphoma). Additionally, the neoplasm presented multifocal areas of haemorrhage and necrosis, characteristic of lymphoma. The parietal and visceral pleura and parietal pericardium were enlarged and covered diffusely with large amounts of a yellowish fibrillary material. The lungs were mildly enlarged, non-collapsed, and firm and exhibited interlobular septae that were thickened with a gelatinous material. Histopathological examination showed that the parietal and visceral pleura were enlarged due to a diffuse and severe inflammatory infiltrate composed of degenerate neutrophils associated with severe fibrin deposition, characteristic of fibrinous pleuropneumonia. Pleura and parietal pericardium fragments were cultivated in aerobic and microaerobic microbiological conditions. Round greyish colonies of gram-negative coccobacilli that were shiny and non-haemolytic were observed in sheep blood agar. The biochemical profile was indicative of Pasteurella spp. Molecular identification was performed by partial $16 S$ rRNA amplification following sequencing. Pasteurella multocida was confirmed as the primary bacterium associated with the bovine fibrinous pleuropneumonia. We are able to infer that the lymphoma caused immunodepression, which increased the animal's susceptibility to atypical infectious microorganisms such as pathogenic P. multocida.
\end{abstract}

Key words: $P$. multocida, bovine pasteurellosis, immunodepression, enzootic bovine leukosis, molecular identification.

Pleuropneumonia fibrinosa causada por Pasteurella multocida associada a linfoma bovino

RESUMO: Nesse trabalho, relatamos um caso de pleuropneumonia fibrinossupurativa causada por Pasteurella multocida associada à linfoadenomegalia em um bovino. O animal apresentava aumento generalizado de linfonodos há um mês progredindo para anorexia e edema submandibular por três dias culminando com óbito. Durante a necropsia, tanto dos linfonodos quanto de diversos órgãos evidenciaram proliferação neoplásica de células arredondadas e arranjadas em mantos (linfoma). Adicionalmente, áreas multifocais de hemorragia e necrose, características de linfoma, foram observadas. As pleuras parietal e visceral e pericárdio parietal apresentavam-se espessas e recobertas por acentuada quantidade de fibrina. Os pulmões estavam aumentados, não colabados, firmes e exibiam espessamento com edema moderado de septos interlobulares. À microscopia, cortes da pleura visceral exibiram acentuado infiltrado inflamatório de neutrófilos degenerados com intensa deposição de fibrina, características da pleuropneumonia fibrinossupurativa, além de neovascularização e proliferação de fibroblastos. Amostras de pulmão e da pleura foram cultivadas em aerobiose e microaerobiose. Evidenciou-se o crescimento puro no ágar sangue ovino de colonias redondas, acinzentadas, brilhantes e não-hemolíticas, sendo caracterizadas como cocobacilos gram-negativos. As características bioquímicas do isolado foram condizentes com Pasteurella spp. Procedeu-se a identificação molecular do isolado através da amplificação parcial do gene rRNA $16 S$ com posterior sequenciamento do produto amplificado. Deste modo foi possível a confirmação do isolado como Pasteurella multocida, sendo o agente primário da pleuropneumonia fibrinosa. Com estes dados, podemos afirmar que o linfoma causou um quadro de imunodepressão, a qual aumenta a susceptibilidade dos animais a agentes infecciosos atípicos, como a P. multocida patogênica. Palavras-chave: P. multocida, pasteurelose bovina, imunodepressão, leucose enzoótica bovina, identificação molecular.

Bovine respiratory disease (BRD) is a multifactorial disease of cattle that may be associated with environmental stress and complex interactions among infectious agents. The underlying processes by which some environmental factors alone or in combination with microorganisms predispose cattle to BRD are not fully understood. Alterations in local innate and adaptive immune responses presumably 
contribute to the development of the disease process (RADOSTITS et al., 2000).

BRD may include shipping fever, characterized by pneumonia or pleuritis caused by Pasteurella multocida, which is commonly observed in calves following exhaustive transport due to stress and other predisposing factors (CASWELL \& WILLIAMS, 2016). Mortality in heifers is less significant, and the disease mainly manifests as reduced weight gain and milk yield and problems with meat quality or fertility (RADOSTITS et al., 2000). In addition, BRD can include fibrinous pneumonia and pleuropneumonia, mainly related to Mannheimia haemolytica (SINGH et al., 2011), which is the most common bacteria isolate from animals with BRD (SINGH et al., 2011). However, WELSH et al. (2004) have suggested that the proportion of fatal cases of respiratory disease in cattle attributable to P. multocida appears to be increasing. Many species of Pasteurellaceae inhabit the upper respiratory tract of healthy animals, but pneumonia occurs only when pulmonary defences are impaired (CASWELL \& WILLIAMS, 2016). P. multocida has long been considered a secondary pathogen, and its role in BRD remains poorly understood (TAYLOR et al., 2010).

Enzootic bovine leukosis (EBL), associated with bovine leukaemia virus (BLV), is a highly contagious condition, and cattle become infected by transfer of BLV-infected B lymphocytes. The disease can be present without obvious clinical signs as persistent lymphocytosis or as a malignant neoplasm. BLV prevalence is higher in adult animals than young animals (MEIRELLES et al., 2009). The main clinical sign of EBL is lymphadenopathy. In addition to evidence that BLV causes host immune depression (FRIE \& COUSSENS, 2015), some studies have suggested that BLV infection increases susceptibility to other infectious diseases (TRAININ et al., 1996).

Here, we describe an uncommon fatal case of fibrinous pleuropneumonia caused by $P$. multocida associated with bovine lymphoma, suggestive of EBL.

A seven-year-old Holstein cow with a one-month history of generalized superficial lymphadenomegaly was presented for necropsy. The cow had been annually vaccinated for clostridia, BVDV, rabies and leptospirosis, and during the last three days it exhibited anorexia and submandibular oedema, resulting in spontaneous death. At necropsy, the thoracic cavity contained 30 litres of a yellowish serous fluid with a small amount of fibrin casts (hydrothorax). The parietal and visceral pleura and parietal pericardium were enlarged and covered diffusely with large amounts of a yellowish fibrillary material (fibrin) (Figure 1A). The lungs were mildly enlarged, non-collapsed, and firm, and exhibited interlobular septae that were thickened with a gelatinous material (oedema). The submandibular, retropharyngeal, inguinal, mesenteric, mediastinal and tracheobronchial lymph nodes were diffusely and severely enlarged and firm, and on the cut surface, the parenchyma was replaced with whitishto-yellowish masses (Figure 1B). The liver and both kidneys were moderately enlarged and diffusely pale. The abomasum wall was diffusely thickened with a whitish mass. The heart presented multiple whitish soft masses along the coronary sulcus. Fragments of the lungs, parietal pleura, superficial and visceral lymph nodes, heart, liver, spleen, kidneys, abomasum, small and large intestines and brain were collected, fixed in $10 \%$ neutral buffered formalin and routinely processed for histopathological examination.

By histopathology, the parietal and visceral pleura were expanded by a diffuse and severe inflammatory infiltrate composed of degenerate neutrophils associated with severe deposition of a fibrillary eosinophilic material (fibrin) (Figure 2A). Adjacent to these areas, there were marked neovascularization and fibroblast proliferation, with a mild inflammatory infiltrate of lymphocytes and plasma cells. The lung parenchyma presented diffuse atelectasis of alveolar spaces and multifocal areas of necrosis and thrombosis.

The parenchyma of the superficial and visceral lymph nodes was obliterated by a dense proliferation of round neoplastic cells. These cells were arranged in mantles and had small eosinophilic cytoplasms and round hyperchromatic nuclei that were sometimes karyorrhectic, with indistinct nucleoli. Anisocytosis and anisokaryosis were marked, with few multinucleate neoplastic cells. Two atypical mitotic figures were observed per high-power field (400x). Additionally, the neoplasm presented multifocal areas of haemorrhage and necrosis. Neoplastic cells were also observed in the abomasum, kidneys, heart (Figure 2B), and small and large intestines. The liver exhibited multifocal centrilobular-to-paracentral necrosis of hepatocytes.

Lung, pleura and parietal pericardium fragments were processed and cultivated under anaerobic and microaerobic conditions in 5\% sheep blood agar, MacConkey agar and chocolate blood agar. The plates were incubated for 48 hours at $37^{\circ} \mathrm{C}$ $7^{\circ} \mathrm{C}$, and individual colonies were then selected for biochemical studies. Round greyish colonies 


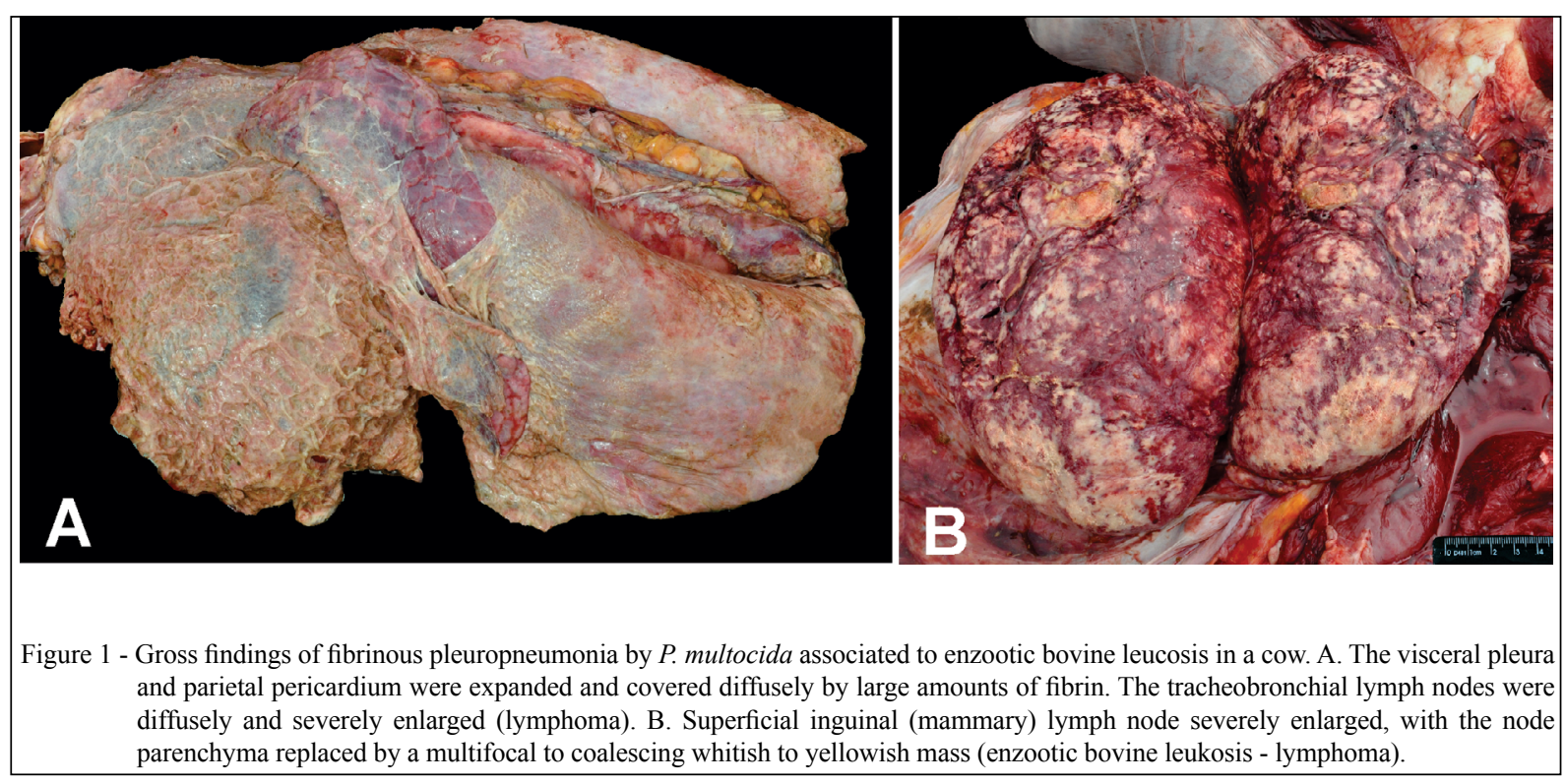

that were shiny and non-haemolytic were observed in $5 \%$ sheep blood agar. Gram staining revealed gram-negative coccobacilli. The biochemical profile was indicative of Pasteurella spp. Furthermore, antimicrobial activity was evaluated in vitro by the agar disk-diffusion method, and the isolate showed susceptibility to penicillin G, amikacin, ceftiofur, enrofloxacin, erythromycin, trimethoprimsulfamethoxazole and tetracycline. Furthermore, the samples were processed and inoculated in Löwenstein-Jensen agar and Stonebrink agar, but no colonies grew after nine weeks of incubation.

For molecular identification, individual colonies were recovered from blood agar, and total bacterial DNA was isolated using a DNeasy Blood \& Tissue Kit (Qiagen, Hilden, Germany), with the addition of proteinase $\mathrm{K}$ (20 $\mathrm{mg} / \mathrm{mL})$. A PCR assay was performed to amplify a partial $16 \mathrm{~S}$ rRNA sequence using the prokaryotic universal oligonucleotides $27 \mathrm{~F}$ (5'-AGAGTTTGATCMTGGCTCAG-3') and 1492R (5'-GGTTACCTTGTTACGACTT-3'). The PCR reactions included $1 \mathrm{U}$ of GoTaq DNA polymerase (Promega, Madison, Wisconsin, USA), 5X GoTaq buffer, 1mM each deoxynucleotide triphosphate, $10 \mathrm{pmol}$ of each primer and 30ng of the total DNA previously extracted in a final volume of $25 \mu \mathrm{l}$. The PCR conditions were as follows: 1 cycle at $94^{\circ} \mathrm{C}$ for $5 \mathrm{~min}$, followed by 35 cycles of $94^{\circ} \mathrm{C}$ for $30 \mathrm{~s}, 55^{\circ} \mathrm{C}$ for $30 \mathrm{~s}$ and $72^{\circ} \mathrm{C}$ for $1.2 \mathrm{~min}$. The negative control was prepared in parallel without genomic DNA. The final extension step was performed at $72^{\circ} \mathrm{C}$ for $10 \mathrm{~min}$. The reaction products were analysed on a $1 \%$ agarose gel.

The 1,450bp amplicons were precipitated by transfer RNA (tRNA) (Invitrogen ${ }^{\mathrm{TM}}$, São Paulo, Brazil) and sequenced in an ABI-PRISM 3500 Genetic Analyzer automatic sequencer (Applied Biosystems Inc. Foster City, CA, USA). The generated sequences were compared with the Blast tool (NCBI database). Sequence matching showed $98 \%$ similarity with $P$. multocida sequences available in the database.

Lesions of acute fulminant pneumonia caused by $M$. haemolytica, Histophilus somni or $P$. multocida cannot be grossly distinguished and include cranioventral fibrinous bronchopneumonia, foci of coagulative necrosis and variable fibrinous pleuritis (CASWELL \& WILLIAMS, 2016). According to DABO et al. (2007), less fulminant bronchopneumonia tends to be more often caused by P. multocida than by M. haemolytica. M. haemolytica is the microorganism frequently related to fibrinous pathological condition (DABO et al., 2007; SINGH et al., 2011), while P. multocida has been described in calves in a few reports (CATRY et al., 2005). Furthermore, the pathological effects of $P$. multocida in swine were recently analysed by experimental inoculation, which caused a severe condition of fibrinous pleuritis, associated with suppurative bronchopneumonia and necrosuppurative pleuropneumonia in finishing pigs (FILHO et al., 2015). The cow in the present report presented severe acute fibrinous pericarditis and

Ciência Rural, v.48, n.5, 2018. 


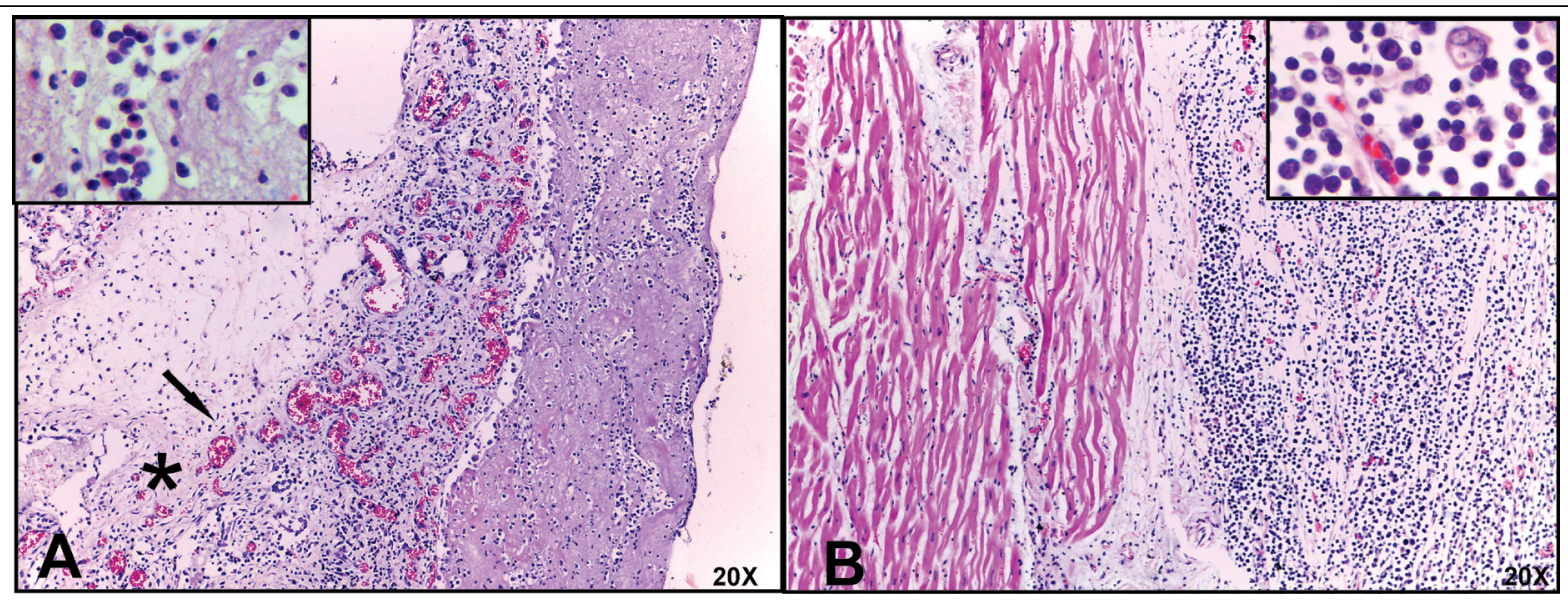

Figure 2 - Histopathology characterization. A. Lung. Visceral pleura was severely expanded by fibrillary eosinophilic material deposition (fibrin) associated with a moderate inflammatory infiltrate of neutrophils (arrow head). Adjacent to these areas there were marked neovascularization and fibroblasts proliferation (asterisk). Upper left corner: details of neutrophils and fibrin deposition. Haematoxylin-eosin stain (HE), 20X. B. Heart neoplastic proliferation of rounded cells arranged in mantles involving mainly the epicardium and infiltrating into the myocardium (lymphoma - enzootic bovine leukosis). Upper right corner: details of neoplastic neutrophils. HE stain, $20 \mathrm{X}$

pleuropneumonia caused by $P$. multocida, enveloping all lung lobes, which are distinct and uncommon gross lesions caused by that bacteria, being the lesions most commonly described in severe cases of shipping fever involving $M$. haemolytica (CASWELL \& WILLIAMS, 2016).

Histological lesions of shipping fever caused by $M$. haemolytica or $H$. somni are characterized by fibrinous and suppurative bronchopneumonia with necrosis of leukocytes ("oatcells"), whereas in the present case, the lesions were mainly localized in the pleura, causing fibrinoussuppurative pleuritis. Interestingly, large necrotic foci in the lung parenchyma have been described only occasionally after $P$. multocida experimental challenge (ISHIGURO et al., 2005), as was observed in the present case.

Multiple predisposing factors are frequently cited for shipping fever, including viral infections (DABO et al., 2007), such as EBL in the present study. This condition increases cattle susceptibility to other infectious diseases (TRAININ et al., 1996; FRIE \& COUSSENS, 2015). $P$. multocida shows a clinical profile similar to that of $M$. haemolytica, resulting in animal death. The virulence profile of $P$. multocida is mainly related to toxin production as well as capsule biosynthesis (DABO et al., 2007), with the toxins being related to the clinical progression. Experimental reproduction of bovine pneumonia with P. multocida and its isolation from cases of naturally acquired bovine pneumonia without evidence of other infectious agents indicate that it can likely occur as a primary pathogen in young or stressed cattle (DABO et al., 2007).

In summary, the death of a cow due to fibrinous pleuropneumonia with $P$. multocida as the aetiological agent associated with a bovine lymphoma is described here. We highlight the importance of bovine leukosis as an immunosuppressive agent predisposing animals to atypical and fatal infections. Furthermore, we demonstrate the advantages of molecular approaches for fast and accurate pathogen identification in animal disease, which could enhance the cattle sanity.

\section{REFERENCES}

CASWELL, J.L.; WILLIAMS, K.J. Respiratory system. In: JUBB, KENNEDY, AND PALMER'S. Pathology of domestic animals. $6^{\text {th }}$ ed. St. Louis, Missouri, Elsevier, 2016. p. 542-546.

CATRY, B. et al. Fatal peritonitis caused by Pasteurella multocida capsular type $\mathrm{F}$ in calves. Journal of clinical microbiology, v.43, n.3, p.1480-1483, 2005. Available from: <https://www.ncbi.nlm. nih.gov/pmc/articles/PMC1081243/>. Accessed: Sept. 23, 2017. doi: 10.1128/JCM.43.3.1480-1483.2005.

DABO, S.M. et al. Pasteurella multocida and bovine respiratory disease. Animal Health Research Reviews, v.8, n.2, p.129-150, 2007. 
Available from: < https://www.ncbi.nlm.nih.gov/pubmed/18218157>. Accessed: Sept. 23, 2017. doi: 10.1017/S1466252307001399.

FILHO, J.O. et al. Pasteurella multocida type A as the primary agent of pneumonia and septicaemia in pigs. Pesquisa Veterinária Brasileira, v.35, n.8, p.716-724, 2015. Available from: <http://dx.doi.org/10.1590/ S0100-736X2015000800003>. Accessed: Sept. 23, 2017.

FRIE, M.C.; COUSSENS P.M. Bovine leukemia virus: A major silent threat to proper immune responses in cattle. Veterinary Immunology and Immunopathology, v.163, n.3-4, p.103-114, 2015. Available from: $<$ https://www.ncbi.nlm.nih.gov/pubmed/25554478 $>$. Accessed: Sept. 23, 2017. doi: 10.1016/j.vetimm.2014.11.014.

ISHIGURO, K. et al. Experimental infection of calves with Pasteurella multocida serovar A:3 isolated in Japan. Journal of Veterinary Medical Science, v.67, p.817-819, 2005. Available from: $<$ https://www.ncbi.nlm.nih.gov/pubmed/16141670>. Accessed: Sept. 23, 2017. doi: 10.1292/jvms.67.817.

MEIRELLES C. et al. Evolution of Enzootic Bovine Leukosis prevalence in an university dairy herd. Semina: Ciências Agrárias, v.30, n.3, p.671-678, 2009. Accessed: Oct. 09, 2017. doi: <http:// dx.doi.org/10.5433/1679-0359.2009v30n3p671>.

RADOSTITS, O.M. et al. Diseases caused by Pasteurella spp., p.829-865. In: Ibid. (Eds), Veterinary Medicine: a textbook of the diseases of cattle, horses, sheep, pigs and goats. $9^{\text {th }}$ ed. Saunders Elsevier, Philadelphia. 2000.

SINGH, K. et al. Mannheimia haemolytica: Bacterial-Host Interactions in Bovine Pneumonia. Veterinary Pathology, v.48, n.2, p.338-348, 2011. Available from: <https://www.ncbi.nlm. nih.gov/pubmed/20685916>. Accessed: Oct. 09, 2017. doi: $10.1177 / 0300985810377182$.

TAYLOR, J.D. et al. Comparison of genotypic and phenotypic characterization methods for Pasteurella multocida isolates from fatal cases of bovine respiratory disease. Journal of Veterinary Diagnostic Investigation, v.22, p.366-375, 2010. Available from: $<$ https://www.ncbi.nlm.nih.gov/pubmed/20453209>. Accessed: Oct. 09, 2017. doi: 10.1177/104063871002200304.

TRAININ, Z. et al. Detrimental effect of bovine leukemia virus (BLV) on the immunological state of cattle. Veterinary Immunology and Immunopathology, v.54, p.293-302, 1996. Available from: <https://www.ncbi.nlm.nih.gov/pubmed/8988875>. Accessed: Oct. 09, 2017.

WELSH, R.D. et al. Isolation and antimicrobial susceptibilities of bacterial pathogens from bovine pneumonia: 1994-2002. Journal of Veterinary Diagnostic Investigation, v.16, p.426-431, 2004. Available from: <https://www.ncbi.nlm.nih.gov/pubmed/15460326>. Accessed: Oct. 09, 2017. doi: 10.1177/104063870401600510. 